\title{
Note
}

\section{Carcass measurements of naked neck and normal chicks}

\author{
A. ZEIN-EL-DEIN, M. ZEINY, H. AYOUB \\ Repartment of Animal Production, Faculty of Agriculture Aïn-Shams, \\ University of Cairo, Egypt
}

\begin{abstract}
Summary
From a cross between two heterozygous parents $(\mathrm{Na} / \mathrm{na}+)$ for the naked neck gene, 10 birds were chosen at random within each sex and each of the two genotypes, $\mathrm{Na} / \mathrm{na}+$ (naked neck) and na+/nat (normal plumage). They were slaughtered at 8 weeks of age. Morphological traits and weights of various parts of the carcass were measured. Plumage in p. 100 of body weight was highly significantly less for naked neck birds in both sexes. Conversely, boneless meat p. 100 and meat/bone ratio in half carcass were significantly higher (respectively at 5 p. 100 and at 1 p. 100 level) for the $N a / n a+$ genotype than for na $+/$ na + . Weight of head (absolute and p. 100 of body weight) was lower for the first genotype (at 5 p. 100 level). The same appeared for heart, but with a genotype $\times$ sex interaction. The main suggested conclusion is, on the whole, a better meat yield for naked neck chicken. Significant effects of sex, on the other hand, were found on various traits independently of genotype at $\mathrm{Na}$ locus.
\end{abstract}

The naked neck gene ( $\mathrm{Na}$ ) has been found associated with lower chick mortality in response to high sublethal temperature (SMITH \& LEE, 1977) and with better growth rate at room temperature kept above $30^{\circ} \mathrm{C}$ till the age of 10 weeks (BorDAs et al., 1978 ; MONNET et al., 1979). In a comparison done in Egypt at two hatching seasons, it was found (ZEIN-EL-DEIN et al., 1981) that heterozygous chicks for the naked neck gene were at an advantage for growth in the hotter season.

Concerning effects associated with this gene on body composition, an important reduction of plumage weight, in absolute terms and in p. 100 of live weight, has been shown (BoRDAs et al., 1978 ; MONNET et al., 1979). These authors did not find significant differences for other carcass components. However, it appeared interesting to do a similar comparison in our local conditions and with measurements partly different from those included in the previous works. 
Chicks were produced by crossing heterozygous $\mathrm{Na} / \mathrm{na}+$ males and females ( $\mathrm{Na}$ being the allele responsible for the naked neck phenotype, nat the normal allele : HutT, 1949 ; Somes ,1980). These parents were progeny of birds sent as day-old chicks in october 1978 from Laboratoire de Génétique Factorielle, I.N.R.A., Jouy-en-Josas (France).

In june 1979, in a hatch including about 100 day-old chicks, 10 birds were chosen at random within each sex and each of the two genotypes, $\mathrm{Na} / \mathrm{na}^{+}$(naked neck) and nat/nat (normal plumage). The $\mathrm{Na} / \mathrm{Na}$ genotype was not considered because two low numbers were available. These birds, raised in flood pens and fed ad libitum, were slaughtered at 8 weeks age. Morphological traits and weights of various parts were measured on carcasses. The different variables are mentioned in table 1. Additional comments can be given as follows :

- weight of feathers is obtained after dry plucking;

- dressed carcass is the difference between plucked carcass and the sum of giblets, viscera, head, neck and shanks + feat; edible portion is the sum of dressed carcass and total giblets;

- dressend carcass is divided into two halves and within one half, the total amount of meat, bone and skin is determined, so that «boneless meat p. 100 » is the proportion of muscle in this half carcass.

Table 1 gives the mean values of measurements and carcass components, for each sex and genotype. Weights are expressed in absolute values and in per cent of live body weight.

Table 2 shows for each trait the $F$ values and significance corresponding to the analysis of variance with genotype at $\mathrm{Na}$ locus and sex as sources of variation. As concerns organ weights only variance analysis on absolute value is presented when significance or absence of significance is the same for the trait expressed in absolute value and in per cent of body weight. However, variance analysis is also presented on percentage for feathers and dressed carcass, where significant effects appear only in this case, and for boneless mat and meat/bone ratio for the same reason.

The aim of the present work was to evaluate the effect of genotype at $\mathrm{Na}$ locus on body composition of chicks. These first results are to be considered as a preliminary indication, in view of the limited numbers available.

The mean live body weights within each sex are higher for the $\mathrm{Na} / \mathrm{na}+$ genotype, as found by ZEIN-EL-DeIN et al. (1981) in this season, but on the present sample, owing to the small numbers, the difference is not significant.

On organ weights expressed in absolute values, our results show a significant effect of genotype $(p<0.05)$ for heart, head and femur, which are lighter on average in naked neck birds. As mean live weight of these birds is superior (not significantly in this small sample but significantly in the larger sample studied by ZEIN-EL-DEIN et al., 1981), these differences would be relatively more important on these variables expressed in per cent of body weight.

The difference between genotypes for feather weight, in absolute value, does not reach significance, but when expressed in p. 100 of live weight, the decrease of plumage weight associated with the $\mathrm{Na} / \mathrm{na}^{+}$genotype becomes highly significant. 


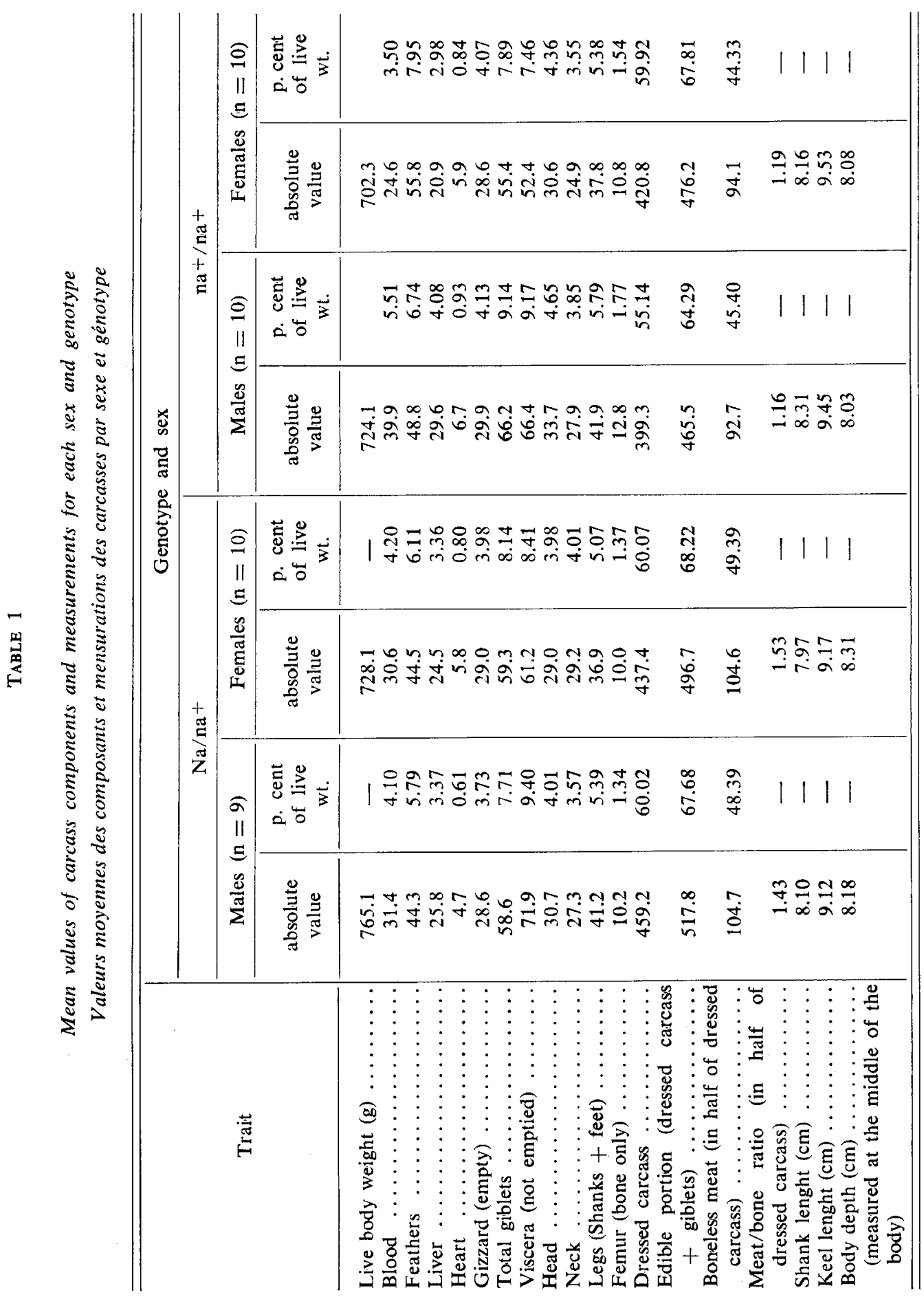


TABLE 2

F. values and significance of variance analysis by sex and genotype at $\mathrm{Na}$ locus for carcass traits

Valeurs de $F$ et signification de l'analyse de variance par sexe au locus Na pour les caractères de carcasse

\begin{tabular}{|c|c|c|c|}
\hline \multirow{2}{*}{ Trait } & \multicolumn{3}{|c|}{ Sourse of variation } \\
\hline & Genotype & Sex & Interaction \\
\hline Live body wt. $\ldots \ldots \ldots \ldots$ & 0.60 & 0.46 & 0.03 \\
\hline Blood $\ldots \ldots \ldots \ldots \ldots$ & 0.22 & $9.47 * *$ & $7.59 * *$ \\
\hline Feathers $\ldots \ldots \ldots \ldots \ldots$ & 3.82 & 0.79 & 0.72 \\
\hline Feathers $\% \ldots \ldots \ldots \ldots$ & $14.25 * * *$ & $4.74^{*}$ & 1.51 \\
\hline Dressed carcass $\ldots \ldots \ldots \ldots$ & 0.17 & 0.02 & 0.41 \\
\hline Dressing $\% \quad \ldots \ldots \ldots \ldots$ & 1.77 & $9.38 * *$ & $4.31 *$ \\
\hline Liver $\ldots \ldots \ldots \ldots \ldots \ldots$ & 0.00 & $7.13 * *$ & 3.94 \\
\hline Heart $\ldots \ldots \ldots \ldots \ldots \ldots$ & $5.34^{*}$ & 0.13 & $4.38^{*}$ \\
\hline Gizzard $\ldots$ & 0.06 & 0.05 & 0.20 \\
\hline Total giblets & 0.34 & 2.44 & 3.21 \\
\hline Viscera .... & 3.14 & $9.36 * *$ & 0.17 \\
\hline Head ......... & $4.88 *$ & $5.17 *$ & 0.47 \\
\hline Neck $\ldots \ldots \ldots \ldots \ldots \ldots$ & 0.95 & 0.09 & 1.61 \\
\hline Legs $\ldots \ldots \ldots \ldots \ldots \ldots$ & 0.18 & $5.02 *$ & 0.00 \\
\hline Femur $\ldots \ldots \ldots \ldots \ldots \ldots$ & $5.50^{*}$ & 2.38 & 1.52 \\
\hline Boneless meat $\% \ldots \ldots \ldots$ & $6.66 *$ & 0.00 & 0.44 \\
\hline Meat/bone ratio $\ldots \ldots \ldots \ldots$ & $7.93^{* *}$ & 0.34 & 0.14 \\
\hline Edible portion $\ldots \ldots \ldots \ldots$ & 0.10 & 0.00 & 0.15 \\
\hline Shank length $\ldots \ldots \ldots \ldots$ & 1.14 & 0.56 & 0.00 \\
\hline Keek length .... & 3.39 & 0.12 & 0.01 \\
\hline Body depth . . . . . . . . & 1.14 & 0.26 & 0.05 \\
\hline
\end{tabular}

Degrees of freedom are 1 for genotype, sex and interaction and 35 for residual.

$*_{\ldots} *_{*} \ldots * * * *_{*}$ : Significant respectively at 5,1 and 0.1 p. 100 level.

Two other traits, expressed respectively as a percentage and as a ratio, show a significant effect of genotype : boneless meat as per cent of eviscerated carcass, and the ratio of meat to bone weight in this carcass. This ratio is significantly $(p<0.01$ ) higher for naked neck chicks.

The effect of sex is significant or highly significant on blood, liver, viscera, head, legs (higher mean for males) and per cent plumage and dressing percentage (higher mean value for females). The sex $\mathbf{x}$ genotype interaction is significant for blood, heart and dressing percentage. However, it may be noticed that in this limited sample the sex dimorphism for live body weight is unexpectedly low, so that the observed effects of sex and sex $\mathrm{x}$ genotype interaction on carcass measurements should be verified on additional data. 
Among differences associated with genotype at $\mathrm{Na}$ locus, that concerning weight of plumage in per cent of body weight is in line with results obtained by BoRDAs et al. (1978) and MONNET et al. (1979). Conversely, the data of Bordas et al. (1978) do not show differences between males of different genotypes at the $\mathrm{Na}$ locus for relative weight of the heart, nor for per cent of bone and muscle, but these percentages concerned only the thigh, while in the present work they relate to the whole carcass.

It will be interesting to confirm this last point, as it is connected with meat yield and thus may be of practical value and suggest some additional advantage of naked neck birds in specific environmental conditions.

Reçu pour publication en octobre 1981.

\section{Résumé \\ Mesures de carcasses sur des poulets cou nu et normaux}

A partir d'un croisement entre deux parents hétérozygotes $(\mathrm{Na} / \mathrm{na}+)$ pour le gène cou $n u, 10$ animaux ont été choisis au hasard dans chaque sexe et chacun des deux génotypes $\mathrm{Na} / \mathrm{na}^{+}(\operatorname{cou} \mathrm{nu})$ et na+na+ (plumage normal). Ils ont été abattus à 8 semaines d'âge et mesurés pour divers caractères morphologiques et poids de parties corporelles. La quantité de plumage en p. 100 du poids du corps était inférieure, de façon hautement significative, pour les poulets cou nu dans les deux sexes. Par contre, le pourcentage de viande désossée et le rapport viande/os dans la demi-carcasse étaient significativement plus élevés (respectivement au seuil 5 p. 100 et au seuil 1 p. 100) pour le génotype $\mathrm{Na} / \mathrm{na}+$ que pour nat/nat. Le poids de la tête (absolu et p. 100 du poids corporel) était moindre pour le premier génotype (au seuil 5 p. 100). Il en était de même pour le cœur, mais avec une interaction génotype $\times$ sexe. La principale conclusion suggérée est, au total, celle d'un meilleur rendement en viande pour les poulets cou nu. D'autre part, indépendamment du génotype au locus $N a$, un effet significatif du sexe était trouvé pour divers caractères.

\section{References}

Bordas A., Mérat P., Sergent D., Ricard F.H., 1978. Influence du gène Na (cou nu) sur la croissance, la consommation alimentaire et la composition corporelle du poulet selon la température ambiante. Ann. Génét. Sél. anim., 10, 209-231.

Hutr F.B., 1949 : Genetics of the fowl. McGraw Hill, New York.

Monnet L., Bordas A., MÉRat P., 1979. Gène cou nu et performances de croissance selon la température chez le poulet. Ann. Génét. Sél. anim., 11, 397-412.

Smith T., Lee R., 1977. A study of the naked neck gene of the fowl. Poult. Sci., 56, 1958 (abstr.).

Somes R.G. Jr., 1980. Alphabetical list of the genes of domestic fowl. J. Hered., 71, 168-174.

Zein-el-Dein A., Ayoub H., Mérat P., 1981. Gène cou $n u$ et performances de croissance à deux saisons différentes en Egypte. Ann. Génét. Sél. anim., 13, 277-287. 